RECYT

Year 23 / No 36 / 2021 / 39-45

\title{
Urban collective housing: safety and hygiene on site. Contributions for the management of excavations, submurations and demolitions
}

\section{Vivienda colectiva en lotes urbanos: seguridad e higiene en obra. Aportes para la gestión de excavaciones, submuraciones y demoliciones}

\author{
R. Bellot' ${ }^{1}$ D. Fiscarelli2, * \\ Laboratorio de Técnicas y Materiales LATMAT. FADU. UNL Santa Fe - Santa Fe. \\ Laboratorio de Tecnología y Gestión Habitacional LATEC. FAU. UNLP. La Plata - BS.As. \\ * E-mail: dfiscarelli@fau.unlp.edu.ar
}

Received: 29/09/2020; Approved: 07/05/2021

\begin{abstract}
In Argentina, public policies related to Safety and Hygiene started at the beginning of the 20th century, and it was not until the 1970s that the first regulations related to the subject were passed, when the current Law $\mathrm{N}^{\circ}$ 19587 on "Safety and Hygiene at Work" was sanctioned. In particular, the construction industry, since 1996, has had a complementary regulatory framework with Decree № 911 . On the other hand, the demolition, excavation and submurder stages found an intervention mechanism with SRT Resolutions N ${ }^{\circ}$ 550/11 and SRT No 503/14. However, the regulatory framework does not provide specificity in relation to procedures and consequently does not guarantee efficiency/effectiveness in operational terms. This work exposes a gap, which, from a particular methodological approach, concludes with the obtaining of results, as it verifies the levels of compliance of the actions in the traceability of the work, aimed at framing the demolition, excavation and submuration tasks according to regulatory parameters of Health and Safety established by the instrument of analysis / matrix. As part of the final considerations, this work proposes to contribute with management guidelines for the aforementioned tasks in urban collective housing works.
\end{abstract}

Keywords: Security; Management; Excavations; Submurations; Demolitions.

\section{Resumen}

En Argentina, las políticas públicas vinculadas con la Seguridad e Higiene comenzaron a principios del Siglo XX; y recién hacia la década del '70 se alcanzó la primera normativa vinculada a la temática, al recibir sanción la vigente Ley № 19587 de "Seguridad e Higiene en el Trabajo". En particular, la industria de la construcción, cuenta desde en el año 1996 con un marco reglamentario complementario con el Decreto № 911. Por su parte, las etapas de demolición, excavación y submuración encontraron un mecanismo de intervención con las resoluciones SRT No 550/11 y la SRT N ${ }^{\circ} 503 / 14$. Sin embargo, el marco regulatorio no proporciona especificidad en relación con los procedimientos y consecuentemente, no garantiza eficiencia/efectividad en términos operativos. Este trabajo expone una vacancia, que, desde un abordaje metodológico particular concluye con la obtención de resultados, en tanto verifica los niveles de cumplimiento de las acciones en la trazabilidad de la obra, orientadas a enmarcar las tareas de demolición, excavación y submuración según parámetros normativos de Higiene y Seguridad establecidos por el instrumento de análisis / matriz. Como parte de las consideraciones finales, este trabajo propone aportar con lineamientos de gestión para las mencionadas tareas, en obras urbanas de vivienda colectiva.

Palabras clave: Seguridad; Gestión; Excavaciones; Submuraciones; Demoliciones. 


\section{Introduction}

According to Rubio Romero and Rubio Gámez (2005), a Management System (MS) is a set of interrelated elements that aim to establish a certain policy and achieve certain objectives ${ }^{1}$. In this sense, the International Labour Organisation states that any Occupational Health and Safety Management System constitutes " [...] a coherent and systematic method of evaluating and improving performance in the prevention of occupational incidents, accidents and diseases" (ILO, 2011). Within the framework of these considerations, this research recognises as a working premise that, in order to carry out the tasks of excavation, submurder and demolition from adequate levels of Health and Safety - hereinafter H\&S -, construction companies of collective housing buildings must address comprehensively, both the planning of activities and the responsibilities of their actors - in addition to their practices, processes and resources. And all this without forgetting the policies that, in relation to what is established by State bodies, allow the definition of the legal and regulatory parameters of each one of them. In this sense, and with the aim of incorporating real and concrete actions, public policies in the Province of Santa Fe - Argentina - have promoted, in recent years, an intentional articulation between business chambers, workers' organisations and technical sectors. The most convincing result refers to the creation of the tripartite commission in 2008, for equal treatment and labour opportunities, which in the field of construction, is formed by the Chamber of Construction, the Building Workers' Union of the Argentine Republic (UOCRA) and the Ministry of Labour.

In response to these initiatives, and contextualizing this research within the framework of current regulations, we find the specific provisions Superintendence of Labour Risks (SRT) 550/11 and SRT 553/14.

The first establishes an intervention mechanism for the stages of demolition of existing buildings, excavations for subsoil and execution of submuracies. It also defines the necessary documentation to accomplish these procedures and establishes a list of primary actions to be carried out by construction companies and health and safety (H\&S) services on site.

The second is a complementary regulation, as it aims to clarify the vacant points that the first and other provisions leave unspecified. In particular, and in relation to the subject of the present work, it defines that for soil movement works, manual or mechanical excavations in the open air that exceed 1.20 metres in depth, as well as for the execution of trenches, wells and any other type of

1- The authors Rubio Romero and Rubio Gámez (2005) use the term management systems from a perspective that coincides with the General Systems Theory, in which organisations are open systems in permanent exchange and, although their component parts can be identified, the system is more than the sum of its constituent elements. excavation not included in SRT No. 550/11, the Employer must adopt certain prevention measures detailed in Annex I thereof ${ }^{2}$.

In response to these initiatives, and contextualising this research within the framework of current regulations, we find the specific provisions SRT 550/11 and SRT 553/14.

The former establishes an intervention mechanism for the stages of demolition of existing buildings, excavations for subsoil and execution of submurations. It also defines the necessary documentation to perform these procedures and establishes a list of primary actions to be carried out by construction companies and on-site H\&S services.

The second is a complementary regulation, as it aims to clarify the vacant points that the first and other provisions leave unspecified. In particular, and in relation to the subject of this paper, it defines that for earthworks, manual or mechanical excavations in the open air that exceed 1.20 metres in depth, as well as for the execution of trenches, shafts and any other type of excavation not included in SRT $\mathrm{N}^{\mathrm{o}} 550 / 11$, the Employer must adopt certain prevention measures detailed in Annex I thereof ${ }^{3}$. Likewise, the regulations address considerations in relation to the management of contingencies already referred to by other authors (Suarez 2004; Macchia 2007), which include safety measures in the event of water ingress, the possibility of fire or falling building materials ${ }^{4}$.Among many other actions, a monitoring and control system is set up by the H\&S service together with the site's Technical Management staff. The purpose of this measure is to periodically check, before and after the works, and particularly after rains or extraordinary situations, the state of the wells, slopes, among others. Thus, and accordingly to the minimum requirements set out in the aforementioned regulations, and taking into account the progress of 'The Techniques and Materials Laboratory' (LATMAT)- Technology and Housing Management Laboratory (LATEC), National University of Litoral - National University of La Plata (UNL-UNLP) research project 'Incidence of accidentology in the construction industry and Health and Safety management technologies in architectural works ${ }^{5}$ and considering that the construction industry accounts for $8.5 \%$ of the total occupational accident rate in the country according to the percentage distribution of cases for each economic activity

2- Art. 5 of SRT 503/14 determines that this resolution does not apply to work in tunnels, underground galleries and mining activities.

3-Art. 5 of SRT 503/14 determines that this resolution does not apply to work in tunnels, underground galleries and mining activities.

4- Before Resolution 503/14 (2014), the architect Oscar Suarez (2004) and the engineer José Luis Macchia (2007) already proposed identical measures as preventive and safety mechanisms, anticipating procedures from on-site praxis.

5- LATMAT --- LATEC - (2018-2020) project, which aims to verify management models for Health and Safety on construction sites in the city of Santa $\mathrm{Fe}$ in the period described, taking as a reference standard the guidelines and regulatory frameworks in force in the field. LATMAT, in coordination with LATEC, proposes to contribute to the definition of procedural guidelines for Health and Safety in order to optimise work execution tasks. 
of the employer to one digit of the ISIC (SRT, 2020), this paper make the first theoretical together with another that refers to the praxis within the framework of the regulations in force such as:

- How do the companies that constitute the study universe approach excavation, submurder and demolition tasks address to the implications of management processes?

- What level of performance do the cases present in relation to the categories that emanate from the resolutions outlined above?

In relation to the methodological segment that this paper deals with as a research section, and as part of the construction of its problem of knowledge, our agreement with Magnosio (2005) the definition of the management criteria for prevention is not integrated with the organisation of the construction company even when the availability of the various parameters established by the regulations, is not usually part of the bilging planning. In addition to this conditioning factor, the criteria stipulated in the aforementioned regulations refer to individual requirements, i.e. they do not constitute variables of a global and integrated procedure that organises the measures aimed at tackling $\mathrm{H} \& \mathrm{~S}$ on site in factual terms.

\section{Materials y Methods}

In methodological terms, the indications described above constitute variables and indicators, which gathered around a normative pattern or analysis matrix, would make it possible to verify the degree of compliance with the H\&S measures of works for the particular tasks mentioned. In other words, this work proposes the formulation of an instrument that will enable to verify the performance of companies in accordance with the with respect to the excavation, submuration and demolition tasks by articulating legal provisions. ${ }^{6}$ Likewise it is proposed that private initiatives linked to excavation, sub-excavation and demolition tasks, inherent in an atypical construction industry as a general context, and to the production of collective housing works in particular, be cut back. In this sense, a qualitative type of research is addressed, which considers as the universe of study, high-rise collective

6- It should be clarified that neither in the Argentinean legislation nor in the technical reports of the official bodies a practical method of occupational risk assessment of the characteristics of the technical note NTP 330 has been found

"Simplified method of occupational risk assessment" of the National Institute of Occupational Safety and Hygiene (Madrid, Spain). In this sense, the proposed instrument conceptually takes up from the aforementioned technical note the key guidelines for risk assessment. Namely:

- The probability of certain risk factors materialising into damage.

- The magnitude of the damage (consequences). Probability and consequences are the two factors whose product determines risk, which is defined as the set of expected damages per unit of time. Probability and consequences. housing projects -between 18 and 24 floors of recent construction in the urban area of the City of Santa Fe and that they had carried out before the execution of the new work, demolitions of the existing buildings. This work recognizes two instances of procedure:

Preliminary Phase: As part of the formulation of the instruments of analysis, a matrix is proposed that recovers from the current regulations, those values or categories that act on the tasks of excavations, submurations and demolitions. This tool corresponds to a double-entry table in whose columns the compliance with the actions that, according to formal and material categories indicated in the rows, are presented by the construction companies of the universe of study -case A, B and C- and regarding the construction tasks in question -demolition, excavation and submuration- is verified -YES/NO-. The first type procedure category - records administrative activities and technical-protocol or regulatory compliance: preparation of the Safety Programme and the annex according to Res. No. 550/11 and 503/14, presence of a permanent $\mathrm{H} \& \mathrm{~S}$ assistant on site, preparation of daily work permits, background in the development of training for staff and inclusion of H\&S-related values in the calculations and budget from the design stage. The category also includes the standardised or protocolised management system in relation to administrative or formal aspects. On the other hand, the execution or material category refers to real and concrete activities: provision and installation of collective and individual safety measures, development of shoring, shoring, access control and circulation tasks.

Second Phase: Considering the instruments of analysis, a study of typical cases is then proposed, with the aim of describing, from a representative casuistry, how H\&S procedures are carried out in the constructive praxis of excavations, submurations and demolitions. The selection criterion of the cases refers to the main construction companies which, according to the Register of Building Permits granted by the borough council of Santa Fe province, have the largest volume built (with the characteristics described) during the period 2018-2019.

The selection cuts itself into 3 (three) cases ${ }^{7}$ that share the following characteristics:

- The companies exceed the payroll of one hundred workers in their construction plant.

- The companies carry out civil works exclusively in the private sector.

- The companies still maintain a constant activity and have a recognised track record - more than 20 years in the construction business.

Likewise, and as a methodological criterion, only

7- In this regard, these three units of analysis (companies), and during the period considered, began various demolition works with the aim of generating "emptiness or waste" and then build high-rise housing buildings. 

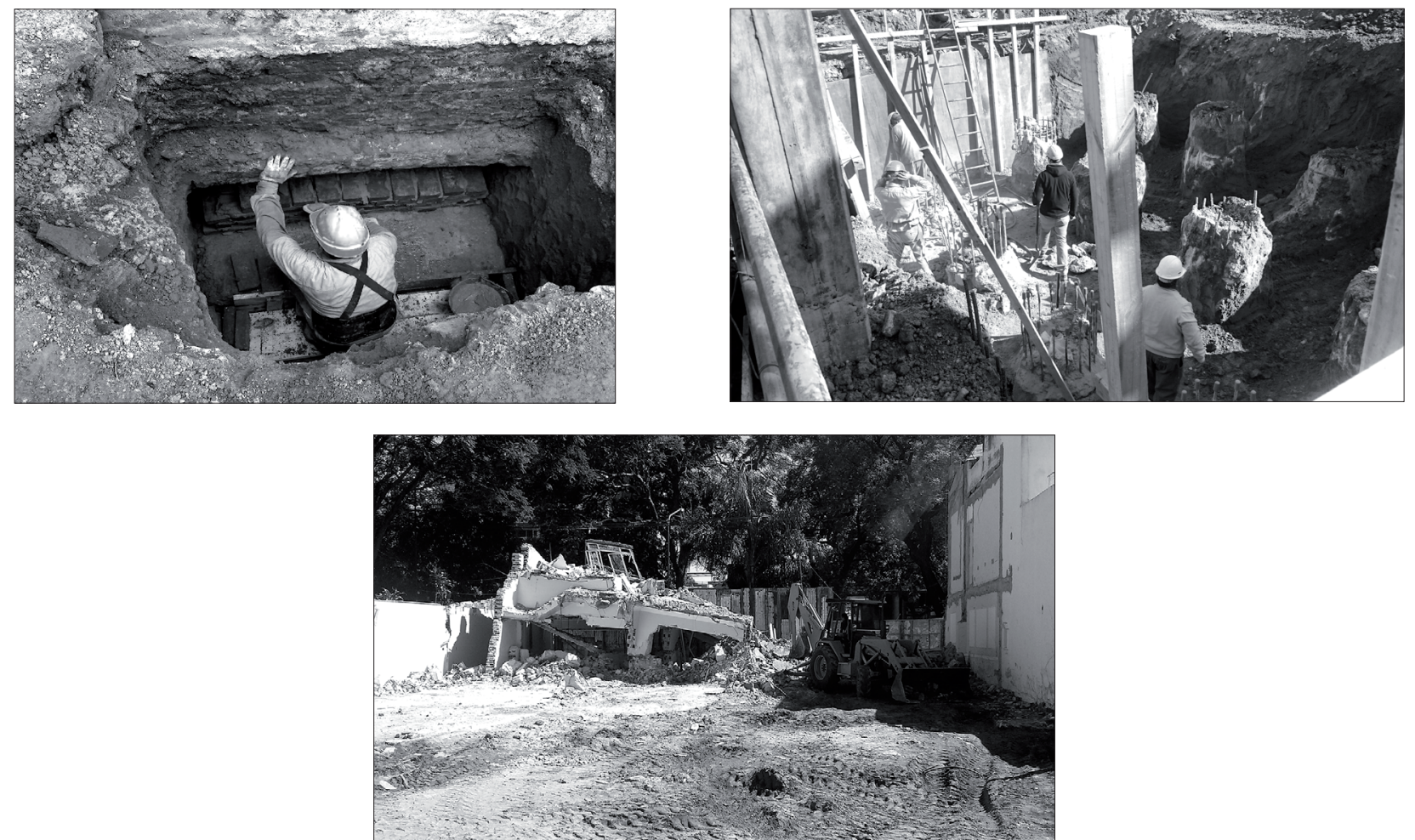

Figure 1 (left): submuring of party walls. Figure 2 (centre): excavation to create subfloors. Figure 3 (right), demolition of existing building. Source: Photographs by the authors.

demolitions of urban residential constructions in plots between party walls and which are configured as ground floor or ground floor and a maximum of one floor are considered. In accordance with this premise, company A carried out 5 (five) demolitions in the period, while companies $\mathrm{B}$ and $\mathrm{C}$ did the same with 3 (three).

Finally, it should be clarified that, for the specific analysis of the excavation task, so many works on subsoil and foundations - piles, heads, etc. - were considered. While for the item "submuration", in all cases the task observed corresponds to the work under the party walls

\section{Results}

In relation to the analysis and as Table 1 states: The companies and other actors in the system register high levels of compliance with regard to administrative and formal aspects, known as the procedural category. On the other hand, in the material aspects, known as the execution category, they show unsatisfactory levels, almost at very low levels with respect to the abovementioned. The difference between the two variables, procedural and enforcement, is almost fifty percent $(\approx 50 \%$ ) between and formal aspects.

In first place, the most relevant aspects of compliance with procedural aspects stand out in full compliance with a S\&H plan drawn up by a specialist and approved by the respective occupational risk insurers (ART) compliance by a permanent technician (auxiliary) with the tasks and daily induction of personnel, recorded by means of books or periodic work permits. To a lesser extent and in a partial manner, training is provided at all levels and the respective budgetary considerations that the matter merits in relation to the volume of work.

Secondly, the least relevant aspects when considering the poor records in the execution aspects are due to the lack of indispensable physical elements such as sheet piling, shoring or retaining walls in the excavations to avoid undesirable and dangerous soil movements, the lack of handrails around open shafts and the absence, to a large extent, of collective safety elements. On the other hand, access and circulation controls (mainly to shafts and excavations) are partially and intermittently complied with. In this stage or executive category, the variable with the highest level of compliance is the provision and use of personal safety equipment. 
Table 1: Analysis matrix | case study | categories procedure and execution

\begin{tabular}{|c|c|c|c|c|c|c|c|c|c|c|}
\hline & \multirow{2}{*}{ ACOONES } & \multicolumn{3}{|c|}{ A } & \multicolumn{3}{|c|}{$B$} & \multicolumn{3}{|c|}{ c } \\
\hline & & OEMOUCOON & EXCAVAOO ON & SUEMURAC. & OE MOUCOON & EXCAVACION & SUSMURAC. & DENOUCOON & EXCAVACION & SUSAURAC \\
\hline \multirow{7}{*}{ 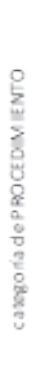 } & PLAN DE SEGURI DAD AP ROBADO & sis & si & si & si & si & si & si & si & si \\
\hline & Ancwo Res. S50/11. 503/14 & s & sI & si & NC & si & si & NC & sil & sil \\
\hline & TEC NICO PERMANENTE & s & sI & si & si & sa & sı & si & si & SI \\
\hline & CONFECCION PERM MSO DIARSO & s & si & sil & si & sil & sil & sil & sil & si \\
\hline & $\begin{array}{l}\text { INCLUSIÓN DE COSTOS EN } \\
\text { PRESUPUESTOS }\end{array}$ & sis & PAR. & PAR & PAR. & PAR & PAR & sil & PAR. & PAR. \\
\hline & $\begin{array}{l}\text { CAPACTTACI ÓN A: mand os medlos Y } \\
\text { superiores }\end{array}$ & NC & si & si & NC & NC & NC & NC & PAR. & NC \\
\hline & SISTEMA de GESTIÓN proto collinado & NC & NC & NC & NC & NC & NC & NC & NC & NC \\
\hline
\end{tabular}

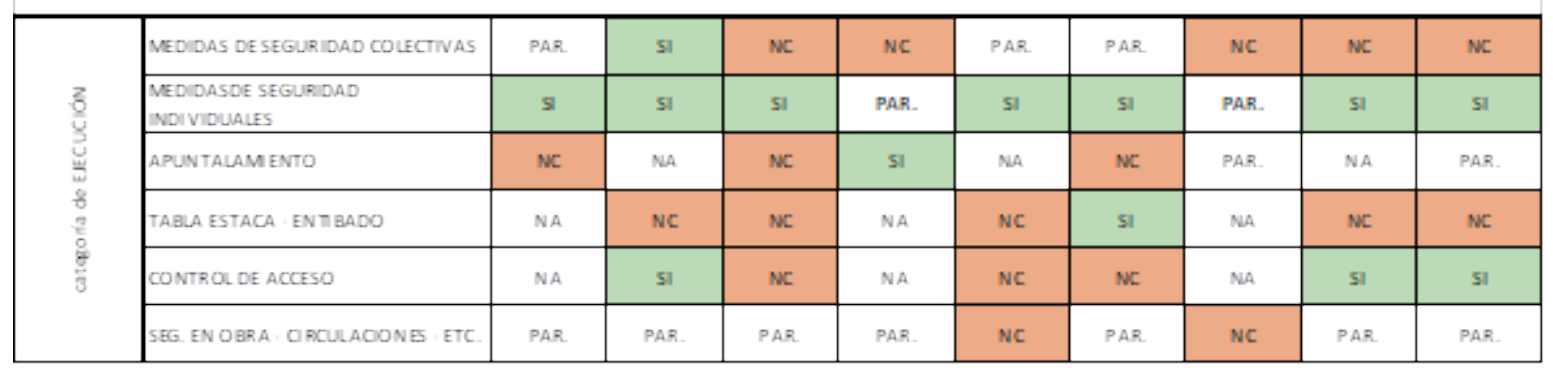

References: Yes $=$ Complies $\mid \mathrm{NC}=$ Does not comply $\mid$ PAR $=$ Partially complies. Source: Authors' elaboration.

Figure 4: shows a summary of the situation, which in percentage terms detects a predominance of formal actions, highlighted in light blue, over material actions, which are in red.

But in particular, and regarding the procedures associated with management, we can verify that the actions carried out by all the companies have not considered - at least in a protocolised manner, i.e. following some regulation or resolution - a Management System, in terms of the parameters described above.

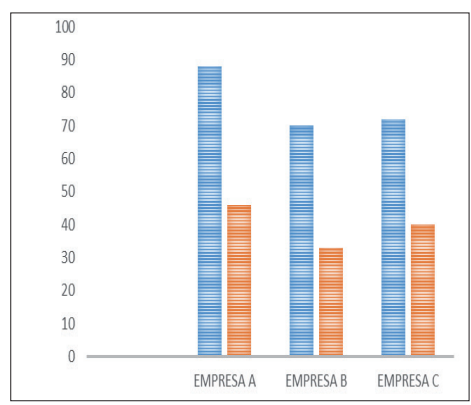

Figure 4: Comparative matrix: companies $\mathrm{A}, \mathrm{B}$ and $\mathrm{C}$. Source: Authors' elaboration.

\section{Analysis and Discussion of Results}

The results presented directly show that in all cases of study: although companies comply to a greater extent with the procedural aspects, related to the shape characteristics, do not do so with the performance or material aspects -especially the physical and visible- without specifying a set of actions to establish a Management System in Health and Safety at Work that allows a continuous improvement in the processes analyzed. Why are resources allocated on procedural rather than implementation aspects? What is the logic of providing personal protection elements, but at the same time neglecting collective protection? Why are middle management such as foremen, supervisors and site managers not trained? Why an efficient management system is not coordinated to support continuous improvement and reduction of incidents and accidents if resources are spent on safety programmes, H\&S services, ancillary services, etc.?

Osorio Puzchini (2016:156) takes up these considerations and points out: "Besides, one of the most important advantages is due to the ease with which workers such as company managers, are aware of the risk factors and their possible outcomes. On the one hand, it means that resources are optimised when acquiring personal and/ or collective protection equipment and, on the other hand, it affects the operator awareness and favours their safety together with their long-term health".

All procedural measures are necessary to ensure that both the work begins and the required permissions are obtained. With the approval of the Safety Programme (SP), the drawing up of the Work Initiation Notice (AIO) and compliance with annexes 550/11 - 503/14, the occupational risk insurance companies (ART) record the formal start of activities in the tasks analysed, as well as suspensions and terminations.

Considering Macchia's expressions (2007), he characterises the construction industry as an activity culturally rooted in precariousness. It is possible to infer that many of the actions carried out in this category have little to do with a real awareness committed to health and safety. In this sense, the main object is strictly bureaucratic fulfilment of the instances of requesting procedures, authorisations and permissions. 
However, if the Occupational Health and Safety Management System together with its set of actions are considered from a referential point of view, (mainly regarding to the management of in relation to demolition, excavation and submuration tasks), it is recognised that continuous improvement is affected in some of the links or gears of the set analysed. It is therefore essential to consider that in addition to the public policies issued as guidelines for proposals, the companies -as an organization that includes workers, middle managers and superiorsestablish detailed planning and concrete application to each working procedure, thinking of it not from the moment but from the beginning of each project. "For this reason, it is necessary to manage the occupational risks present in each task to be carried out for each particular work site" (Gómez, 2015:1).

\section{Conclusions}

It can be affirmed that the evaluation of any process should not and cannot be confined to the mere drawing up of a record or register of non-compliance in documents intended for this purpose - orders and services book but, on the contrary, it must awaken an alarm light that generates effective actions such as training, agendas in $\mathrm{H} \& \mathrm{~S}$ committees and decision making by the various managers linked to the activity. In this sense, evaluation is not in itself an instance that should produce mere recommendations, by contrast, it is an activity that should generate actions.

On the other hand, it is also stated that if the technical procedures, necessary for each site, are not contemplated in the management system, nor are the respective $\mathrm{H} \& \mathrm{~S}$ expenditures included in the initial budgets and a risk is assumed as a starting condition in terms of planning. In this sense, the cost is not only the preparation of a safety programme and a permanent technician but also the value of a fine. It is essential to consider the investment in material elements such as sheet piling, props, shoring, personal protective equipment and, at the same time, the management to use them correctly and at the right time.

Therefore, to promote continuous H\&S improvement, it is essential to manage all excavation, demolition and submurder activities, not only from the organisation and compliance with procedural public policies, but also from the planning and evaluation of executive aspects, involving all levels of company organisation, diagnosing shortcomings and proposing the resolution of critical areas. In this way a virtuous circle will be achieved in the pursuit of continuous improvement in the production and management processes of safe works.

\section{References}

1. Decreto 0510/2008. Creación de la Comisión Tripartita para el Trabajo Decente. Provincia de Santa Fe. 3 de Marzo de 2008.

2. Gómez, M. de los A. (2015) Análisis de Riesgos en la Etapa de Excavación y Submuración en Obras de Construcción. -Trabajo Final de Especialización- Especialización en Higiene y Seguridad en el Trabajo. Universidad Tecnológica Nacional.

3. Ley $\mathbf{N}^{\circ}$ 19587. Ley de Higiene y Seguridad en el Trabajo. Presidencia de la Nación. 21 de Abril de 1972.

4. Macchia, J. L. (2007). Prevención de accidentes en las obras: conceptos y normas sobre higiene y seguridad en la construcción. Buenos Aires (Argentina). Ed. Nobuko.

5. Mangosio J. E. (2005). Seguridad en la Construcción. Buenos Aires (Argentina). Ed. Nueva Librería.

6. Ministerio de Trabajo, Empleo y Seguridad Social; Ministerio de Educación; Instituto Nacional de Educación Tecnológica; Oficina de Pais de la OIT para Argentina (2014). Salud y Seguridad en el Trabajo (SST). Aportes para una cultura de la prevención. Buenos Aires (Argentina).

7. Nota técnica NTP: 330. Método simplificado de evaluación de riesgos laborales. Instituto Nacional de Seguridad e Higiene en el Trabajo. Madrid. (España). Año 1993.

8. Osorio Puzchini (2016). Proyecto de Seguridad e Higiene para rubros de excavaciones y submuraciones. -Trabajo Final de Especialización. Especialización en Higiene y Seguridad en la Industria de la Construcción. FAU. Universidad Nacional de La Plata.

9. Resolución 550/2011. Riesgo del Trabajo. Etapas de demolición, excavación y ejecución de submuraciones - obras en construcción. Superintendencia de Riesgos del Trabajo. 6 de Abril de 2011.

10. Resolución 503/2014. Trabajos de movimiento de suelos, excavaciones manuales o mecánicas a cielo abierto. Superintendencia de Riesgos del Trabajo. 12 de Marzo de 2014.

11. Rubio Romero, J.C. y Rubio Gámez, M. del C. -Directores | Coordinadores- (2005). Manual de coordinación de seguridad y salud en las obras de construcción. Madrid (España). Ed. Díaz de Santos.

12. Suarez, O. (2004). La seguridad en las obras. Buenos Aires (Argentina). Ed. Revista Vivienda. 


\section{Web sites}

13. Información Legislativa. Disponible en: http://.infoleg.gob. ar. [Consultado el 22/04/2021].

14. Ministerio de Trabajo, Empleo y Seguridad Social (MTEySS). Disponible en: https://argentina.gob.ar/trabajo. [Consultado el 22/04/2021].

15. Organización Internacional del Trabajo (OIT). Disponible en: https://.ilo.org/global/lang--es/index.htm. [Consultado el 22/04/2021].

16. Superintendencia de Riesgos del Trabajo (SRT): https://.argentina.gob.ar/srt. [Consultado el 22/04/2021]. 